Case 2723

\title{
Phororhacos Ameghino, 1889 (Aves, Gruiformes): proposed conservation
}

\author{
Luis M. Chiappe \& Miguel F. Soria
}

Museo Argentino de Ciencias Naturales, Av. Angel Gallardo 470, 1405 Buenos Aires, Argentina

\begin{abstract}
The purpose of this application is to conserve the name Phororhacos Ameghino, 1889, which has been widely used for a genus of fossil giant flightless birds from South America. The name was first published as Phorusrhacos Ameghino, 1887, based on a single bone then thought to be mammalian, but although this spelling did not appear again for 75 years and was rejected in 1968 as a nomen oblitum it has had extensive recent usage.
\end{abstract}

1. In 1887 Ameghino (p. 24) proposed a new genus and species, Phorusrhacos longissimus, based on a fragmentary mandible found in Miocene deposits in southern Patagonia, Argentina (although Ameghino interpreted them as Eocene). He assumed the bone to be mammalian (Edentata, or anteaters, armadillos and sloths).

2. In 1889 Ameghino (p. 659) emended the generic name to Phororhacos, and proposed a family PHORORHACOSIDAE. The family name was corrected to PHORORHACIDAE by Lydekker (1893, p. 43) and this spelling was accepted by Ameghino and all subsequent workers.

3. Ameghino (1891a, p. 255) realized that P. longissimus was a giant flightless bird. Based on a series of finds he described further species of Phororhacos (1891a, 1891b, $1895,1897,1898,1900-1903,1904,1910)$. On a single occasion $(1898$, p. 235$)$ the genus appeared as Phororhacus, but elsewhere in that paper it was spelled Phororhacos and we assume that Phororhacus was simply a misprint.

4. Phororhacos has been used as a valid fossil bird genus by numerous workers (e.g. Lydekker, 1893; Mercerat, 1897; Andrews, 1896, 1899; Glangeaud, 1898; Rovereto, 1914; L. Kraglievich, 1920, 1929-32, 1931a, 1931b, 1932, 1940; Sáez, 1927a, 1927b, 1936; Sinclair \& Farr, 1932; Cabrera, 1939; Patterson, 1941; J.L. Kraglievich, 1946; Piveteau, 1950, 1955; Patterson \& J.L. Kraglievich, 1960; Romer, 1966; Rusconi, 1967; Cracraft, 1968, 1969; Marshall, 1978).

5. Sclater (in a footnote (p.41) in Lydekker's 1893 paper), Loomis (1914) and Mathew \& Granger (1917) used the incorrect spellings Phororhacis, Phororhacus and Phororhachos respectively.

6. Except for Brodkorb $(1963,1967$; see para. 7 below) no workers had used the name Phorusrhacos since Ameghino's first paper of 1887 when Cracraft (1968, p.33, footnote), citing Article $23 \mathrm{~b}$ of the Code then in force, formally rejected it as a nomen oblitum (i.e. a name not used as valid for more than 50 years and with a junior synonyn in general use). That Article said that 'a nomen oblitum is not to be used unless the Commission so directs', and added '... zoologist who discovers such a name is to refer it to the Commission...'. Cracraft was correct in his rejection, although he did not refer 
the case to the Commission. Article 79c(iii) of the present Code says 'A name must not be used without the approval of the Commission [our italics] if it was rejected... [as a nomen oblitum in 1968]... To remove uncertainty, the case should be referred to the Commission asking for the suppression of the rejected name'. This shows that Cracraft's omission to refer the case in 1968 did not invalidate his rejection of Phorusrhacos Ameghino, 1887, and we are applying for its suppression.

7. Brodkorb (1963, p. 111, footnote) considered Phorusrhacos valid, and he also proposed the replacement family name PHORUSRHACIDAE. He repeated this point of view in his 1967 Catalogue of fossil birds (pp. 157, 162-165). Brodkorb's resurrection of a name which had been used only once ( 75 years earlier and based on a single fragmentary bone not then recognized as avian) was completely unjustified.

8. Despite this, most recent authors have followed Brodkorb and used Phorusrhacos (Feduccia, 1980; Tonni, 1980; Mourer-Chauviré, 1981, 1983; Alvarenga, 1982; Cracraft, 1982; Olson, 1985a, 1985b; Tonni \& Tambussi, 1986, 1988; Vuilleumier, 1987; Caroll, 1988; Peters, 1989). In total, however, far more workers (see para. 4, and also others) have used Phororhacos.

9. Under Article 40a of the Code the family name PHORORHACIDAE Ameghino, 1889 (the correct spelling of PHORORHACOSIDAE: see para. 2) which has been widely used (e.g. by authors listed in para. 4), is valid and is not to be replaced by PHORUSRHACIDAE Brodkorb, 1963. It would be highly confusing to have different valid spellings (Phorusrhacos, PHORORHACIDAE) for the genus and the family. Since two spellings of both names have been used we request a definitive resolution from the Commission.

10. The International Commission on Zoological Nomenclature is accordingly asked:

(1) to use its plenary powers to suppress the generic name Phorusrhacos Ameghino, 1887 (rejected as a nomen oblitum by Cracraft, 1968) for the purposes of the Principle of Priority but not for those of the Principle of Homonymy;

(2) to place on the Official List of Generic Names in Zoology the name Phororhacos Ameghino, 1889 (gender: masculine), type species by indication under Article 67 h of the Code Phorusrhacos longissimus Ameghino, 1887;

(3) to place on the Official List of Specific Names in Zoology the name longissimus Ameghino, 1887, as published in the binomen Phorusrhacos longissimus (specific name of the type species of Phororhacos Ameghino, 1889);

(4) to place on the Official List of Family-Group Names in Zoology the name PHORORHACIDAE Ameghino, 1889 (type genus Phororhacos Ameghino, 1889);

(5) to place on the Official Index of Rejected and Invalid Generic Names in Zoology the name Phorusrhacos Ameghino, 1887, as suppressed in (1) above;

(6) to place on the Official Index of Rejected and Invalid Family-Group Names in Zoology the following names;
(a) PHORORHACOSIDAE Ameghino, 1889 (an incorrect original spelling of PHORORHACIDAE);
(b) PHORUSRHACIDAE Brodkorb, 1963 (name of the type genus suppressed in (1) above).

\section{Acknowledgments}

We want to thank Drs A. Bachman and J.F. Bonaparte (Museo Argentino de Ciencias Naturales) and the Commission Secretariat for their useful comments, and also Dr A. Walton (Southern Methodist University) who reviewed the English manuscript. 


\section{$2 \mathrm{BHL}$ Biodiversity Heritage Library}

Bouchet, Philippe. 1990. "Comments On The Proposed Conservation Of Limax Fibratus Martyn, 1784 And Nerita Hebraea Martyn, 1786 (Currently Placostylus Fibratus And Natica Hebraea, Mollusca, Gastropoda)." The Bulletin of zoological nomenclature 47, 202-203. https://doi.org/10.5962/bhl.part.2712.

View This Item Online: $\underline{\text { https://www.biodiversitylibrary.org/item/44488 }}$

DOI: https://doi.org/10.5962/bhl.part.2712

Permalink: https://www.biodiversitylibrary.org/partpdf/2712

\section{Holding Institution}

Natural History Museum Library, London

\section{Sponsored by}

Natural History Museum Library, London

\section{Copyright \& Reuse}

Copyright Status: In copyright. Digitized with the permission of the rights holder.

License: http://creativecommons.org/licenses/by-nc-sa/3.0/

Rights: https://biodiversitylibrary.org/permissions

This document was created from content at the Biodiversity Heritage Library, the world's largest open access digital library for biodiversity literature and archives. Visit BHL at https://www.biodiversitylibrary.org. 